УДК 338.124 .4

Возняк Галина, доктор економічних наук, старший науковий співробітник, ДУ «Інститут регіональних досліджень імені М. І. Долішнього НАН України», провідний науковий співробітник відділу регіональної фінансової політики, м. Львів; ORCID ID: 0000-0003-2001-0516 e-mail: gvoznyak@gmail.com

Жеребило Ірина, кандидат філософських наук, доцент, директор Львівського навчально-наукового інституту, ДВНЗ «Університет банківської справи», м. Львів; ORCID ID: 0000-0002-3147-9590 e-mail: zherebilo@gmail.com

https://doi.org/10.29038/2411-4014-2020-03-51-57

\title{
МІНЛИВІСТЬ ЕКОНОМІКИ В УМОВАХ ПАНДЕМІЇ: ФІНАНСОВО- ЕКОНОМІЧНІ НАСЛІДКИ ДЛЯ КРАЇНИ ТА ТЕРИТОРІАЛЬНИХ ГРОМАД
}

В статті досліджуються наслідки впливу пандемії для економічного та соціального розвитку територіальних громад та України загалом. Проаналізовано фінансово-економічні виклики, акцентовано на потенційних загрозах. Виявлено проблемні аспекти як в секторах економіки, так і в державних та місцевих фінансах. Доведено, що динамічні зміни в усіх сферах діяльності потребують миттєвих відповідних стратегічних і тактичних рішень. 3 метою мінімізації впливу пандемії на сталий розвиток країни та громад запропоновано низку коротко та середньострокових ініціатив в частині: державної підтримки найбільш вразливих секторів економіки; фінансової підтримки вразливих верств населення; компенсації втрат доходів місцевих бюджетів.

Ключові слова: невизначеність, пандемія, криза, фінансово-економічні виклики, мінливість економіки.

Возняк Галина, доктор экономических наук, старший научный сотрудник, ДУ «Институт региональных исследований им. М. И. Долишнего НАН Украины», ведущий научный сотрудник отдела региональной финансовой политики, г. Львов

Жеребило Ирина, кандидат философских наук, доцент, директор Львовского учебно-научного института ГВУЗ «Университет банковского дела» г. Львов

\section{НЕОПРЕДЕЛЕННОСТЬ ЭКОНОМИКИ В УСЛОВИЯХ ПАНДЭМИИ: ФИНАНСОВО-ЭКОНОМИЧЕСКИЕ ПОСЛЕДСТВИЯ ДЛЯ СТРАНЫ И ТЕРРИТОРИАЛЬНЫХ ОБЩИН}

В статье исследуются последствия влияния пандемии для экономического и социального развития территориальных общин и Украины в целом. Проанализированы финансово-экономические вызовы, акцентировано на потенциальных угрозах. Выявлены проблемные аспекты как в секторах экономики, так и в государственных и местных финансах. Доказано, что динамические изменения во всех сферах деятельности требуют мгновенных соответствующих стратегических и тактических решений. С целью минимизации влияния пандемии на устойчивое развитие страны и общин предложен ряд коротко и среднесрочных инициатив в части: государственной поддержки наиболее уязвимых секторов экономики; финансовой поддержки уязвимых слоев населения; компенсации потерь доходов местных бюджетов.

Ключевые слова: неопределенность, пандемия, кризис, финансово-экономические вызовы, изменчивость экономики. 
Halyna Voznyak,
Dr. Sc. (Economics), Senior Research Fellow, Leading Researcher of
Department of Regional Financial Policy
SI "Institute of Regional Research
named after M.I. Dolishniy of the NAS of Ukraine", Lviv

Zherebylo Iryna,

Ph. D. in Philosophical Sciences, Associate Professor, Director of Lviv Educational-Scientific Institute of SHEI «Banking University»,

Lviv

\section{ECONOMY VARIABILITY IN A PANDEMIC: FINANCIAL AND ECONOMIC IMPACTS FOR COUNTRIES AND TERRITORIAL COMMUNITIES}

The new challenges posed by the effects of the COVID 19 pandemic have exacerbated a number of risks to the continued functioning and sustainable progress of both local communities and the country as a whole. The pandemic, combined with the Government's measures to contain and spread the virus, had a negative impact on the country's economy and local communities. In this context, the need to assess existing and potential challenges and threats to the economic and social development of the country and communities was raised.

The purpose of the article is to analyze the financial and economic consequences of the pandemic for the sustainable progress of both communities and Ukraine and to justify anti-crisis measures aimed at overcoming the challenges.

The methodology of scientific research of economic variability in a pandemic and its impact on the economic and social development of territorial communities and the country is based on the use of the principles of a systematic approach, structural analysis and generalization.

The peculiarities of the functioning of the economy in a pandemic in Ukraine in terms of key activities are revealed. Financial and economic challenges are analyzed, emphasis is placed on potential threats. Problematic aspects have been identified both in the economic sectors and in state and local finances. It is proved that dynamic changes in all spheres of activity require instant appropriate strategic and tactical decisions. In order to minimize the impact of the pandemic on the sustainable development of the country and communities, a number of short- and medium-term initiatives have been proposed: government support for the most vulnerable sectors of the economy (including tax holidays; moratorium on business inspections; 0\% SSC for entrepreneurs working in the most affected) »Industries); financial support for vulnerable groups; compensation for losses of local budget revenues (renewal of Article 103 of the Budget Code of Ukraine).

Keywords: uncertainty, pandemic, crisis, financial and economic challenges, economic variability.

Постановка проблеми. На початку 2020 року Україна, як і весь світ, стикнулися із новими викликами, обумовленими наслідками пандемії COVID - 19 - глобальним карантином та соціальноекономічною кризою. Станом на сьогодні відсутнє чітке бачення поступу, немає уяви щодо змін на найближчу перспективу в жодній галузі економіки. Водночас, більшість прогнозів та експертних досліджень свідчать про неминучість змін в системі організації виробництва, сфері послуг, на ринку праці, а відтак і в сфері соціально-економічних відносин загалом. Пандемія в сукупності із впровадженими Урядом заходами, щодо стримування та поширення вірусу, негативно позначились на економіці України. Рецесія, обумовлена COVID - 19, (за прогнозами МВФ, очікується в Україні падіння ВВП - 8,2\% порівняно із 2019 роком), вже вплинула на життя людей (вимушена/часткова незайнятість, втрата доходів домогосподарств, зростання безробіття, обмеження доступу до публічних послуг) та економіку (згортання економічної діяльності підприємств, скорочення робочих місць, недоотримання доходів, відсутність ресурсів для інвестицій, падіння попиту на продукцію власного виробництва, руйнування ланцюгів постачання тощо). Динамічні зміни в усіх сферах діяльності потребують миттєвих відповідних стратегічних і тактичних рішень (фінансових, управлінських, комунікативних і ін.), а тому на часі питання протидії можливим загрозам та викликам сталому поступу України та громад. 
Зазначене актуалізує озвучену проблематику та свідчить про нагальну необхідність оцінювання існуючих та потенційних викликів сталого поступу країни та громад, обгрунтування коротко та середньострокових ініціатив мінімізації впливу пандемії.

Аналіз останніх досліджень, у яких започатковано вирішення проблеми. Окреслена тематика в силу своєї соціально-економічної значимості перебуває в фокусі наукових досліджень представників економічної та фінансової науки. Так, проблеми розвитку територіальних громад, їх фінансового та інституційного забезпечення, управління спільними ресурсами задля досягнення колективного блага, оцінювання структурних дисбалансів місцевих бюджетів широко представлено в науковому доробку як вітчизняних (М. Баймуратов, О. Батанов, В. Бесчастний, П. Жук, І. Луніна, О. Кириленко, В. Опарін, Н. Спасів), так і зарубіжних вчених (М. Олсон, Е. Остром, А. Токвіль, П. Гураль, К. Іонассен, Д. Хіллері). Проблеми та перспективи сталого розвитку економік активно дискутуються в роботах таких вчених як: P. Chasek, L. Wagner, F. Leone, N. Risse. Обговорення теоретичних засад розумної економіки та визначення можливих шляхів ії реалізації відбувається в дослідженнях А. Сафіулліна, Д. Хосперса. Попри значний доробок, на даний час, проблема дослідження мінливості економіки в контексті її впливу на сталий поступ як громад, так і країни загалом в умовах непередбачуваних ситуацій, нових викликів та загроз є недослідженою, а отже потребує додаткового вивчення та обговорення.

Метою статті $\epsilon$ аналіз фінансово-економічних наслідків пандемії для сталого поступу як громад, так і України та обгрунтування антикризових заходів, спрямованих на подолання викликів.

Виклад основного матеріалу. Світова криза, обумовлена пандемією коронавірусу COVID-19, несе в собі окрім загроз здоров'ю населення, негативний вплив на економічну активність в країнах, загострення цілої низки проблем, економічного, фінансового, соціального характеру. За оцінками МВФ у 2020 році світовий ВВП скоротиться на 4,9\%, а світова економіка втратить 12,5 трильйонів доларів. Економічна ситуація $\epsilon$ невизначеною, а економіка - мінливою. За таких умов часова невизначеність та глибина економічних наслідків обумовлює появу ризиків та фінансовоекономічної нестабільності.

Наслідком глобальних шоків для України та запровадження Урядом низки обмежувальних протиепідемічних заходів стало, стрімке падіння економіки (рис.1), попри існування реально працюючих механізмів стримування інфляції, оздоровленої банківської системи, найбільших 32012 року золотовалютних резервів (26 млрд доларів) та більш досконалої (порівняно із минулими роками) структури економіки.

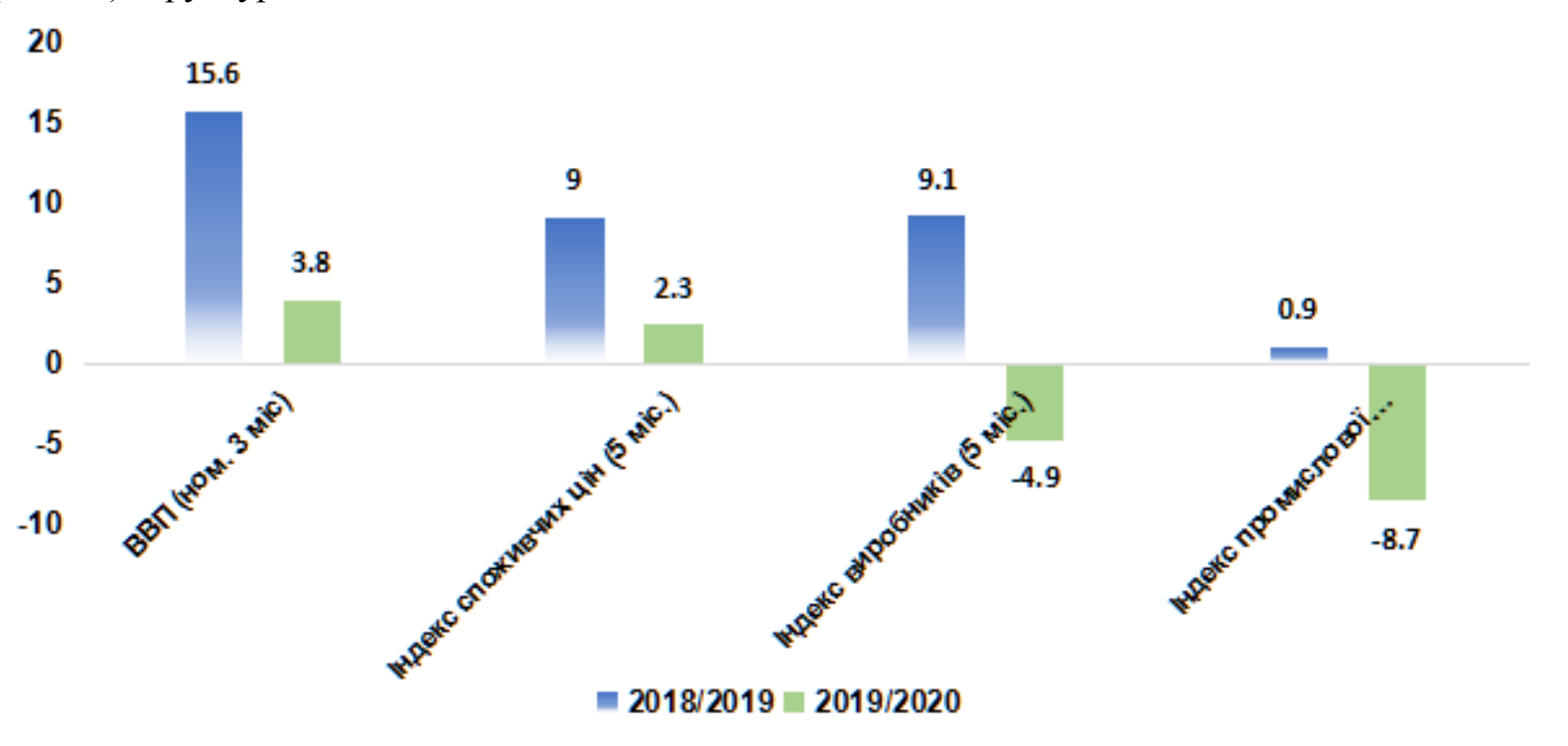

Рис. 1. Основні індекси нащіональної економіки, \%

Джерело: дані Держстату без тимчасово окупованої території Криму та зони проведення АТО [1].

Так, за даними Державної служби статистики, на кінець 2 кварталу 2020 року падіння промисловості склало (-48\%), готельно-ресторанний бізнес (-82\%), оптова і роздрібна торгівля (-31\%), адмінпослуги (-27\%), освіта і культура (-70\%), будівництво (-13\%), вантажні та пасажирські перевезення (-24\%) i 
ін. Зрозуміло, що цьому є певне пояснення: економія доходів населення (через невпевненість в майбутньому) призвела до закриття ринків та магазинів, а відтак і до скорочення роздрібного товарообору; суттєве падіння промисловості обумовлене зниженням інвестиційного попиту (хоча є i такі галузі, яким криза сприяла відновленню, наприклад, виробництво масок та санітайзерів); залізничні та автомобільні перевезення перебувають в прямій залежності від карантинних заходів. Справедливості заради зазначимо, що попри негативні наслідки пандемії, позитиву додають зростання на чверть безготівкових розрахунків, в тому числі за рахунок торгівлі онлайн і помірне стримування інфляції .

Серед галузей економіки, які зазнали найбільшого негативного впливу пандемії є індустрії, які побудовані на соціальній взаємодії, а це, насамперед, туристична галузь і супутні з нею (пасажирські перевезення, готелі, ресторани, заклади культури, парки, атракціони тощо). Це вагома проблема в масштабах України, адже загалом сектор послуг складає понад $60 \%$ економіки України Якщо дивитись в територіальному розрізі України, то суттєво карантинні заходи позначились на економіках Львівської, Одеської, Закарпатської, Івано-Франківської та Київської областей. За оцінками експертів станом на травень 2020 року туристична галузь України вже втратила 1,5 млрд доларів [2], а прогнози щодо ії відновлення ніхто не береться робити. Очевидно, що без державної підтримки відновити галузь буде надто важко. Негативно вплинула економічна криза і на IT сектор (комп'ютерне програмування та надання інформаційних послуг). За оцінками експертів понад $60 \%$ діючих в Україні компаній зменшили заробітну платню своїм працівникам через зменшення замовлень та затримку виплат за діючи контрактами.

Усвідомлюючи негативні наслідки для економічного та соціального розвитку як громад, так i країни загалом Уряд переглянув макропоказники, порівняно із докризовими. Граничний обсяг дефіциту бюджету на 2020 рік (після його перегляду) сягнув 7,5\% ВВП, а сума боргу зросла до 2,4 трлн грн (60\% ВВП, хоча на кінець 2019 року державний і гарантований складали 50\% ВВП). Прогнозне падіння реального ВВП Урядом передбачено на рівні -4,8\% [3].

Цілком очевидно, що погіршення економічної активності в країні негативно позначилось на наповнюваності бюджетів (як державного, так і місцевих). Якщо проаналізувати надходження до бюджету, наприклад, від ПДФО в розрізі ключових бюджетоформуючих галузей, то картина $€$ чітким відображенням невтішних економічних процесів в цих галузях. Найгірша ситуація по надходженнях ПДФО станом на травень 2020 року спостерігалась в оптовій і роздрібній торгівлі (падіння до 80\%), інші галузі «просіли» від 10 до 30\% (рис.2).

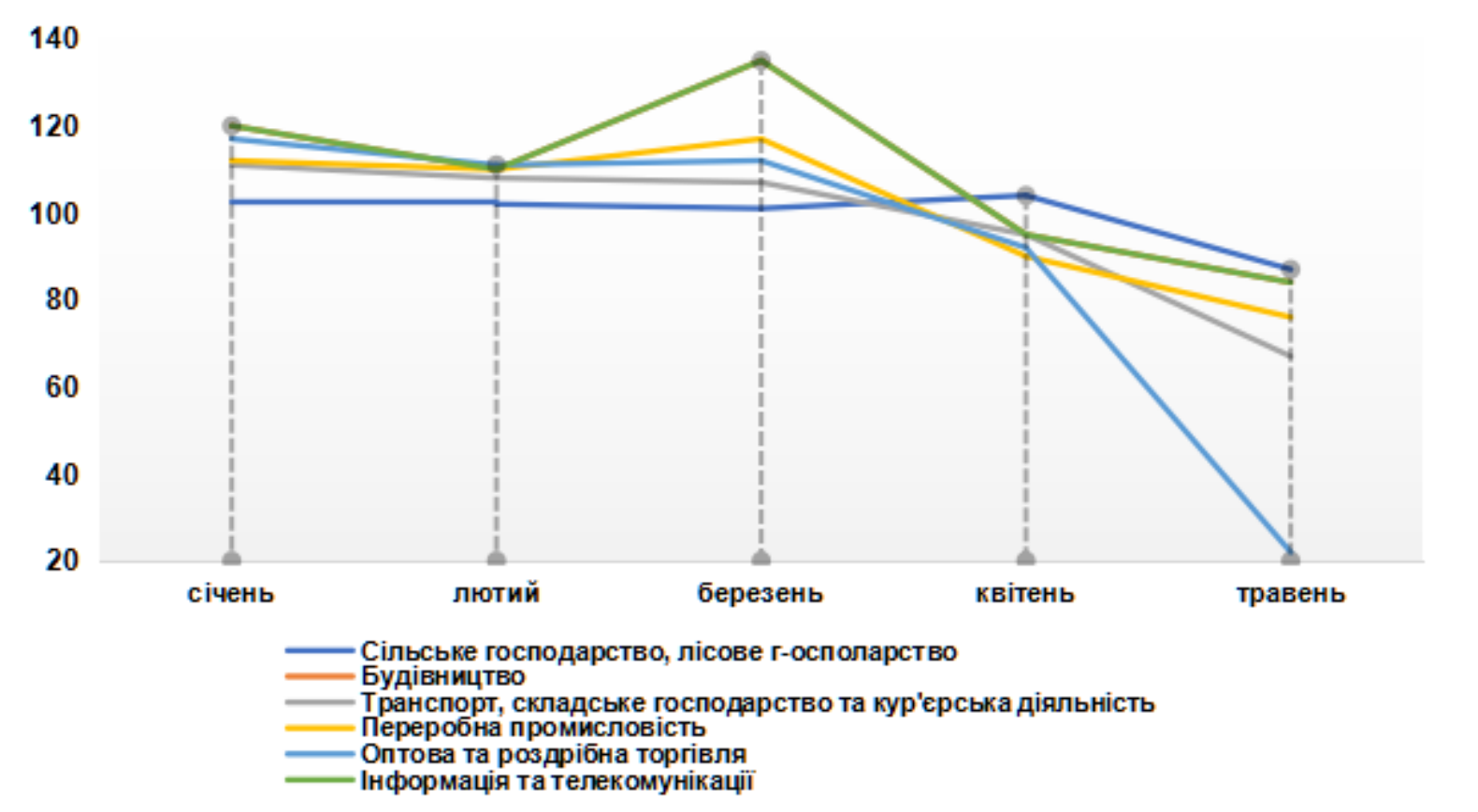

Рис.2. Темпи росту надходжень від ПДФО (2020/2019), \%

Джерело: дані Державної податкової служби України [4]. 
За даними Державної казначейської служби на травень 2020 року ситуація із наповненням бюджету від податкових та митних органів склали $88 \%$ аналогічного періоду минулого року і тільки $65 \%$ від плану цього року. Загалом за перше півріччя 2020 доходи Державного бюджету за загальним фондом було виконано на 92,1\% і в абсолютному вимірі складали 450,9 млрд грн [5].

Якщо ж аналізувати виконання доходів місцевих бюджетів України за перше півріччя 2020 року, то недовиконання плану склало $10,4 \%$. Найгірше виглядає ситуація зі сплатою податку на землю приріст надходжень по сплаті податку на землю складав -14,5\% порівняно з аналогічним періодом минулого року. За даними Державної казначейської служби України [5] в першому півріччі 2020 року до місцевих бюджетів України із врахуванням трансфертів надійшло 224886,7 тис грн, що на $21 \%$ менше аналогічного періоду 2019 року (рис.3). Невтішна ситуація по виконанню місцевих бюджетів, в тому числі і ОТГ в частині: недоотримання надходжень по податку на нерухоме майно, відмінне від земельної ділянки та ПДФО, скорочення надходжень від яких відбулись через прийняті зміни до податкового законодавства щодо підтримки платників податків у зв'язку із здійснення заходів, спрямованих на запобігання виникнення і поширення коронавірусної хвороби COVID-19. Щодо зменшення доходів місцевих бюджетів в частині трансфертної підтримки, то воно об'єктивне, оскільки у 2020 році не здійснюються окремі видатки, пов'язані із реалізацією державних програм соціального захисту (стосується виплат допомоги сім'ям 3 дітьми, малозабезпеченим, виплати субсидій населенню), хоча з іншого боку $100 \%$ скорочення фінансування інфраструктурної субвенції для ОТГ та $15 \%$ для соціально-економічного розвитку не є свідченням державницької політики сприяння сталому поступу громад. Інакше кажучи, негативні існуючі тенденції з наповненням бюджетів усіх рівнів $є$ свідченням в тому числі запровадження карантинних заходів у зв'язку 3 пандемією COVID19.

Така ситуація не могла не позначитись на ринку праці. В уточненому прогнозі економічних показників на 2020 рік Уряд передбачив зростання рівня безробіття з 8,1\% до 9,4\%, з одночасним скороченням заробітної плати з 12500 грн до 11500 грн [3]. В силу обмежувальних заходів, пов'язаних із карантином, роботодавці змушені були відправити своїх працівників у неоплачувані відпустки чи звільнити. Ясна річ, що це позначилось на показниках безробіття. Так, згідно даних Державного центру зайнятості [6] від початку карантину 146270 осіб отримали статус безробітного, що вдвічі більше аналогічного періоду минулого року. Роботу змогли знайти 79 тисяч осіб.
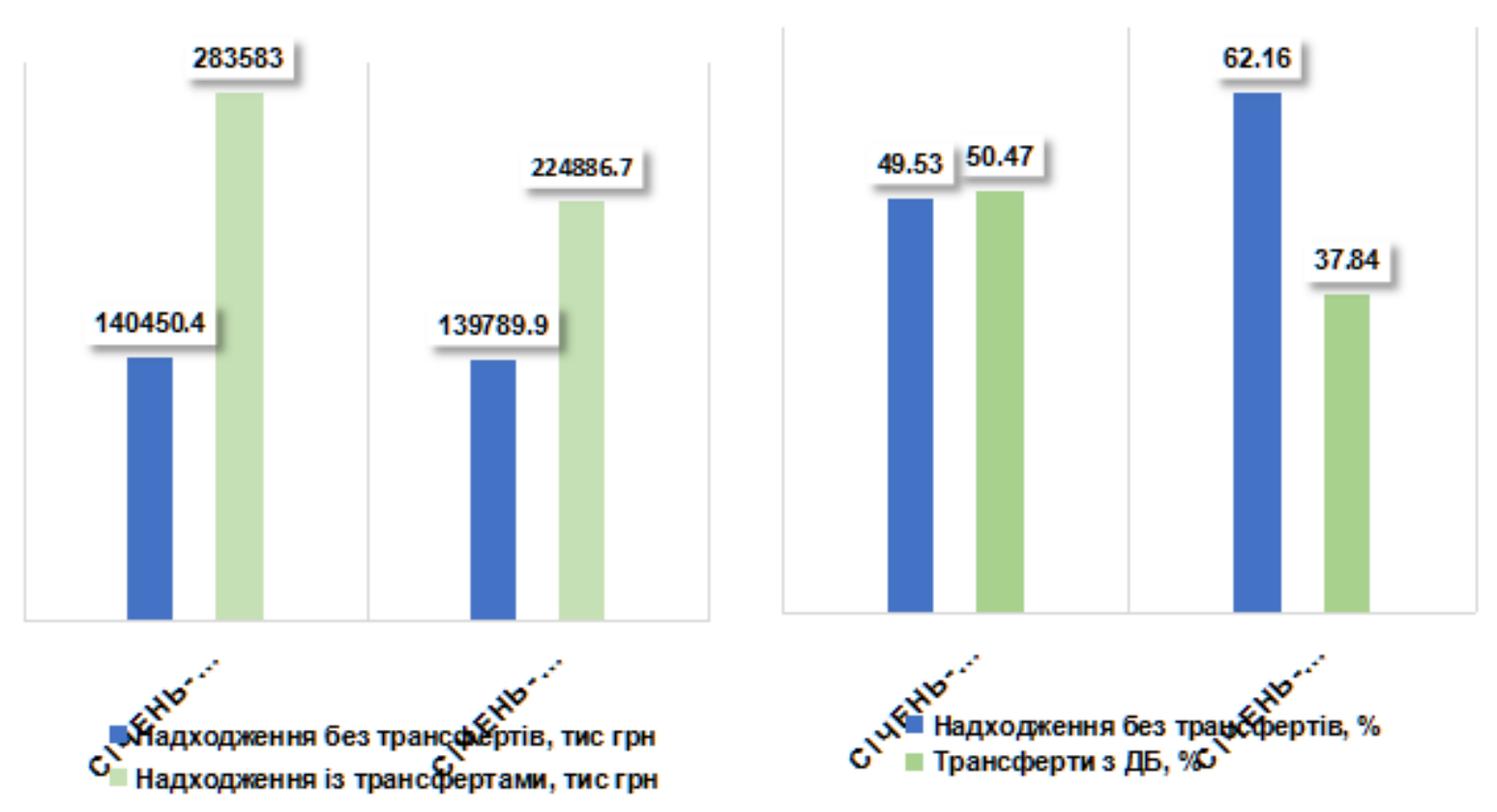

Рис. 3. Доходи місиевих бюджетів за 2019-2020, тис грн, \%

Джерело: дані Державної казначейської служби України [5] . 
Інший негативний тренд цього року - зменшення інвестиційних надходжень. Відомий факт, що найбільшими іноземними інвестиціями в Україну є перекази заробітчани. Очевидним $є$ і те, що уповільнення економічного зростання в країнах ЄС неминуче призвело до втрати робочих місць трудових мігрантів з України, а отже і до скорочення грошових переказів. До слова, якщо в 2019 році ці перекази в Україну склали 12 млрд доларів, то в цьому році, за оцінками Національного банку, очікують скорочення до 10 млрд доларів. В умовах невизначеності також не варто очікувати інвестицій в силу того, що потенційні інвестори послабили інтерес до нових ринкових економік (інвестують в більш надійні активи).

Висновки та пропозиції. Спираючись на проведений фінансово-економічний аналіз наслідків пандемії COVID - 19 для економіки в першій половині 2020 року вважаємо, що серед короткострокових ініціатив мінімізації впливу пандемії на економіку країни та громад можливі такі:

- економічне відновлення галузей, які понесли найбільші збитки без державної підтримки $\epsilon$ неможливим. Видається, що на часі запровадження заходів, які стимулюватимуть економічне відновлення життєво важливих секторів, серед таких можливі: податкові канікули; мораторій на перевірку бізнесу; 0\% ССВ для ФОП, які працюють в найбільш «постраждалих» галузях тощо. До порівняння зазначимо, якщо ж дивитися як світові Уряди намагаються підтримати власну економіку і стимулювати бізнес в умовах коронавірусу, то: Італія (виділено 25 млрд євро) призупинила виплати 3 позик та іпотеки, як для фізичних, так і юридичних осіб (завдяки державним гарантія для банків), запровадила допомогу сім'ям в розмірі 600 євро для оплати послуги нянь на час карантину; Франція (300 млрд євро допомоги) - відклала впровадження суперечливої пенсійної реформи; Велика Британія (виділила 350 млрд фунтів) - спрямувала чималу суму коштів на підтримку малого бізнесу, туризму та авіагалузі; Америка 1 трлн дол виділила допомоги бізнесу та домогосподартствам (що $є$ в рази більше, аніж на подолання кризи 2008 року) [7]. Тобто обсяги допомоги та стимулювання залежать від фінансово-економічного становища країни до кризи;

- переорієнтування виробництва на дистанційну роботу є теж одним із потенційних шляхів відновлення економіки (до речі, яскравим прикладом $\epsilon$ платформа інтернет-торгівлі Alibaba в Азії);

- 3 огляду на дефіцит бюджету та обмежені можливості доступу до ресурсів, видається, що виправданим буде швидке таргетування вузьких секторів економіки чи окремих груп населення (тим, хто втратив засоби до існування чи з низьким рівнем доходу), позаяк очікуваний ефект для економіки буде позитивним; для секторів економіки, які зазнали нищівних збитків (туризм, авіаперевезення тощо) доцільно запровадити адресну фінансову підтримку, можливо кредитні гарантії;

- оскільки прийняті зміни до податкового законодавства щодо підтримки платників податків у зв'язку із здійснення заходів, спрямованих на запобігання виникнення і поширення коронавірусної хвороби, призвели до непередбачуваних втрат місцевих бюджетів ОТГ від надходжень місцевих податків таких як плата за землю та податок на нерухоме майно, відмінне від земельної ділянки, то логічним кроком зі сторони держави має бути компенсація таких втрат доходів бюджетів. В цьому випадку є сенс відновити дію статті 103 Бюджетного кодексу України.

\section{Джерела та література}

1. Державна служба статистики України. URL: http://www.ukrstat.gov.ua/ (дата звернення: 26.06.2020).

2. Туризм після карантину: як пандемія вплинула на галузь i змінила iii. URL: https://dyvys.info/2020/05/14/turyzm-pislya-karantynu-yak-pandemiya-vplynula-na-galuz-i-zminyla-yiyi/ ～(дата звернення 10.08.2020).

3. Постанова КМУ від 29 березня 2020 р. № 253 «Про внесення змін до постанови Кабінету Міністрів України від 15 травня 2019 р. № 555». URL: https://zakon.rada.gov.ua/laws/show/253-2020-\%D0\%BF\#Tехt (дата звернення 25.06.2020)

4. Державна податкова служба України. URL: https://tax.gov.ua/ (дата звернення: 25.06.2020)

5. Державна Казначейська служба України. URL: https://www.treasury.gov.ua/ua/file-storage/kvartalnij-zvitpro-vikonannya-derzhavnogo-byudzhetu-ukrayini-za-pershe-pivrichchya-2020-roku?page=1 (дата звернення 09.07.2020).

6. Державний центр зайнятості. URL: https://www.dcz.gov.ua/ (дата звернення 09.07.2020) 
7. Коронавірус i економіка. Чи все так погано в Україні через карантин. URL: https://www.bbc.com/ukrainian/features-51944639 (дата звернення 09.07.2020)

\section{References}

1. Derzhavna sluzhba statystyky.[ State Statistics Service]. Retrieved from: http://www.ukrstat.gov.ua/ (Accessed 26 June 2020). [in Ukrainian].

2. Turyzm pislya karantynu: yak pandemiya vplynula na haluz' i zminyla yiyi. [Tourism after quarantine: how the pandemic affected the industry and changed it.] Retrieved from: https://dyvys.info/2020/05/14/turyzm-pislyakarantynu-yak-pandemiya-vplynula-na-galuz-i-zminyla-yiyi/ (Accessed 10 August 2020). [in Ukrainian].

3. Kabinet Ministriv Ukrainy. (2020). Pro vnesennya zmin do postanovy Kabinetu Ministriv Ukrayiny : postanova Kabinetu Ministriv Ukrainy vid 15.05.2019. № 555. [Resolution of the Cabinet of Ministers of March 29, 2020 № 253 “On Amendments to the Resolution of the Cabinet of Ministers of Ukraine of May 15, 2019 № 555”]. Retrieved from: https://zakon.rada.gov.ua/laws/show/253-2020-\%D0\%BF\#Text (Accessed 25 June 2020). [in Ukrainian].

4. Derzhavna podatkova sluzhba Ukrayiny. [State Tax Service of Ukraine]. Retrieved from: https://www.treasury.gov.ua/ua/file-storage/kvartalnij-zvit-pro-vikonannya-derzhavnogo-byudzhetu-ukrayini-zapershe-pivrichchya-2020-roku?page=1 (Accessed 25 June 2020). [in Ukrainian].

5. Derzhavna Kaznacheys'ka sluzhba Ukrayiny. [State Treasury Service of Ukraine]. Retrieved from: https://www.treasury.gov.ua/ua/file-storage/kvartalnij-zvit-pro-vikonannya-derzhavnogo-byudzhetu-ukrayini-zapershe-pivrichchya-2020-roku?page=1 (Accessed 09 July 2020). [in Ukrainian].

6. Derzhavnyy tsentr zaynyatosti. [State Employment Center]. Retrieved from: https://www.dcz.gov.ua/ (Accessed 09 July 2020). [in Ukrainian].

7. Koronavirus i ekonomika. Chy vse tak pohano v Ukrayini cherez karantyn. [Coronavirus and the economy. Is everything so bad in Ukraine because of quarantine]. Retrieved from: https://www.bbc.com/ukrainian/features51944639 (Accessed 09 July 2020). [in Ukrainian].

Стаття надійшла до редакції 13.08. 2020 р. 